KAWISTARA

VOLUME 4

No. 2, 17 Agustus 2014

Halaman 111-224

\title{
MARTABAT DALAM ITS WAVERING IMAGE KARYA PENULIS PEREMPUAN CHINA-AMERIKA, SUI SIN FAR
}

\author{
Juliasih Kusharyanto \\ Fakultas Ilmu Budaya Universitas Gadjah Mada \\ Email: Juliasih.k@gmail.com
}

\begin{abstract}
Multicultural society in the United States is depicted as a mosaic, composed of a variety of races and ethnic groups that have always been different from one another. Some people argue that multiculturalism may undermine solidarity. The designation African-American, Native-American, Asian-American, Hispanic-American, and many more to certain groups of people in a society may cause hostility or even disintegration. Sui Sin Far in Its Wavering Image expresses her dissenting opinions. She who supports diversity which is the main issue in America asserts that cultural differences have always existed. A person can be an American and can still be able to maintain another cultural identity. She believes that all human beings are born free and are equal in dignity and rights. Thus, those who live in a heterogeneous society can be considered as a dignified society. Multicultural feminism theory is applied to identify the inequalities induced by cultural, racial, ethnic, and sexual diversity.
\end{abstract}

Keywords: Dignity, Multicultural Feminism, Intellectual, Harmony, Belief

\begin{abstract}
ABSTRAK
Masyarakat multikultural di Amerika digambarkan seperti mosaik yang terdiri dari berbagai bangsa, dan kelompok etnis yang selalu berbeda antara satu dengan yang lain. Beberapa orang berargumen bahwa multikulturalisme dapat melemahkan solidaritas. Penamaan African-American, NativeAmerican, Asian-American, Hispanic-American, dan seterusnya bagi kelompok-kelompok orang sebenarnya cenderung menyebabkan permusuhan dan bahkan disintegrasi. Sui Sin Far dalam karyanya Its Wavering Image mengungkapkan perbedaan pendapatnya. Dia yang mendukung keberagaman yang menjadi isu utama di Amerika menyatakan bahwa perbedaan budaya ada selama ini. Seseorang dapat menjadi orang Amerika dan masih tetap dapat mempertahankan identitas budaya lainnya. Dia percaya bahwa semua manusia dilahirkan bebas dan sama dalam martabat dan hak-haknya. Dengan demikian, mereka yang hidup dalam masyarakat yang heterogen pantas untuk disebut sebagai masyarakat bermartabat. Teori feminisme multikultural diaplikasikan untuk mengidentifikasi ketidaksetaraan yang disebabkan oleh perbedaan budaya, ras, etnis, dan jenis kelamin.
\end{abstract}

Kata kunci: Martabat, Feminisme Multikultural, Intelektualitas, Harmoni, Kepercayaan 


\section{PENGANTAR}

Pada tahun 1970 feminisme di Amerika diwarnai dengan pemikiran tentang ras oleh Angela Davis (1983), dan Bell Hooks (1990, 2000). Mereka melihat bahwa feminisme yang ada pada waktu itu tidak mewadahi aspirasinya. Feminism tersebut hanya fokus pada persoalan mereka sendiri, sedangkan permasalahan dan latar belakang perempuan berbeda karena perbedaan ras dan etnik. Dasar pemikiran ini memunculkan feminisme multikultural. Mereka melihat bahwa terdapat pembedaan sikap dan perlakuan tidak adil terhadap kelompok masyarakat tertentu. Feminis multikultural menentang gagasan bahwa semua perempuan memiliki pandangan dan pikiran sama tentang penyebab ketidakadilan atau ketidaksetaraan, dan mengatasnamakan perempuan pada umumnya (Okin, 1999, Tronto, 2006:426, Tong, 2008: 309-310). Menurut Feminisme multikultural semua perempuan tidak diciptakan atau dikonstruksi secara setara, bahkan di dalam satu negara sekalipun. Mereka percaya bahwa "Everyone is born free and equal in dignity and rights" (setiap orang dilahirkan bebas dan sama dalam martabat dan hak-haknya) seperti yang tercantum dalam Universal Declaration of Human Rights (2008). Setiap orang berhak atas semua hak dan kebebasan yang diatur dalam Deklarasi tersebut, tanpa pembedaan apapun antara lain ras, etnis, warna kulit, jender, bahasa, agama, politik atau status lainnya. Feminisme tidak pernah berhenti menghadapi, menyikapi, dan memperjuangkan setiap tantangan baik berupa gerakan atau pemikiran seperti disebutkan sebelumnya (Butler, 2004: 8). Secara garis besar, pemikiran feminism multikultural berhubungan dengan pemikiran multikultural, yaitu suatu ideologi yang mendukung keberagaman (Tong, 2008:310). Isu tersebut sampai saat ini menjadi pembicaraan di Amerika Serikat karena negara tersebut merupakan tempat masyarakat multikultural yang digambarkan seperti mosaik yang terdiri berbagai bangsa, ras, dan kelompok etnis yang berbeda. Menurut feminisme multicultural bahwa etnis dan ras sulit berasimilasi untuk menjadi satu kelompok karena pada dasarnya mereka tidak mau "kehilangan" identitas mereka. Akan tetapi, tidak semua orang Amerika sependapat dengan pemikiran tersebut karena tujuan para generasi sebelumnya adalah kesatuan sesuai dengan semboyan Amerika, yaitu berbeda-beda tetapi satu. Para imigran bahkan bertekad datang ke dunia baru dan menjadi manusia baru. Mereka meleburkan diri dan menyebut Amerika sebagai melting pot. Para imigran ini berargumen bahwa multikulturalisme dapat melemahkan solidaritas. Menurut mereka penamaan African-American, Native-American, Asian-American, Hispanic-American, dan seterusnya sebenarnya cenderung memecah belah. Dalam perkembangannya, gerakan sosial intelektual yang mempromosikan nilai-nilai keberagaman sebagai suatu prinsip dasar menuntut bahwa semua kelompok kebudayaan harus diperlakukan dengan penuh penghargaan dan sebagai manusia yang setara (Dinnerstein, 1977, Gilman, 2006: 14-15). Para pendukung multikulturalisme melihat "keunikan" Amerika Serikat dalam keberagaman karena setiap orang dapat menunjukkan perbedaan keyakinannya tanpa harus memaksakan kehendaknya kepada orang lain (Hadi, 2000: 126). Hal ini merupakan hak asasi manusia yang mendasar untuk mempertahankan budayanya sendiri (Kymlicka, 1995). Sui Sin Far, seorang feminis dan penulis Cina Amerika pendukung multikulturalisme mengatakan bahwa perbedaan budaya tetap ada. Seseorang dapat menjadi orang Amerika dengan tetap mempertahankan identitas budaya aslinya. Menurutnya bahwa mereka yang hidup dalam masyarakat heterogen berhak untuk menjaga martabat.Pemikiran Sui Sin Far menggarisbawahi pemikiran feminisme multikultural yang menyatakan bahwa kesetaraan ras, etnis, dan jender berhenti pada tataran ideologiserta belum sampai pada tataran operasional atau tataran instrumental yang bersifat aplikatif dan kontekstual. Dasar pemikiran ini mendorong feminis multikultural untuk memisahkan 
diri dan membentuk kelompok baru setelah berpuluh tahun berada dalam satu wadah. Bagi feminis multikultural, feminisme yang ada tidak lagi sesuai dengan aspirasi. Mereka melihat bahwa perbedaan justru merupakan bagian dari kesetaraan yang dijalin dan direkat oleh nilai-nilai multikultural seperti yang ditawarkan oleh Sui Sin Far. Seperti diketahui bahwa teori feminisme tidak hanya menyampaikan pokok-pokok pikiran yang berkaitan dengan konsep dan teori, tetapi menawarkan juga solusi untuk mengurangi bahkan menghapus ketidaksetaraan. Oleh karena itu, para penulis feminis termasuk Sui Sin Far tidak saja berbicara tentang permasalahan ketidaksetaraan yang berkaitan secara langsung dengan perempuan, tetapi dia juga membicarakan tentang ketidaksetaraan yang dialami manusia pada umumnya. Pada karya-karyanya, Far menawarkan beberapa solusi seperti yang terdapat dalam Its Wavering Image. Bagi Sui San Far menjaga martabat merupakan dasar dalam masyarakat heterogen yang juga tertera dalam Deklarasi Hak-hak Azasi Manusia seperti yang telah disebutkan sebelumnya, tetapi definisi martabat sulit untuk dijabarkan. Bahkan, dalam Kamus Besar Bahasa Indonesia (2007:717) martabat diartikan tingkat harkat kemanusiaan dan harga diri yang pemaknaannya baru dapat dipahami melalui konteks. Oleh karena itu, penelitian ini bertujuan untuk mencari makna kata martabat, terutama mencermati nilainilai apa saja yang terkandung didalamnya dan bagaimana nilai-nilai tersebut terimplementasi dalam Its Wavering Image. Hal ini akan diteliti dengan menerapkan teori feminisme multikultural dan metode kualitatif yang melibatkan sejumlah besar gejala sosial yang relevan (Ratna, 2004:47). Penelitianini akan melibatkan pengarang dan lingkungan sosial di mana pengarang berada, termasuk unsur-unsur kebudayaan pada umumnya. Metode ini mencari makna dan mengungkap pesan yang tersembunyi dibalik keseluruhan teks baik yang berupa pernyataan, ungkapan, maupun pemikiran individu maupun kelompok. Metode ini memanfaatkan cara-cara penafsiran dengan menyajikannya dalam bentuk deskripsi.

Tulisan ini juga bertujuan menerapkan teori feminisme multikultural untuk pengembangan kajian perempuan yang merupakan teori yang kompleks karena terkait dengan berbagai aspek, antara lain aspek sosial, budaya, dan ekonomi. Dibandingkan dengan teori lain, teori ini belum dikenal secara luas. Padahal penelitian feminis multikultural memberikan tempat sentral tidak hanya bagi perempuan, tetapi bagi masyarakat juga pada umumnya. Dengan demikian, secara teoritis penelitian ini diharapkan dapat ikut membantu menyebar luaskan dan mengembangkan penggunaan teori feminisme multikultural. Secara praktis penelitian ini bertujuan membantu dan memperluas wawasan pembaca pada umumnya untuk memahami feminisme dari sudut multikulturalisme melalui pemikiran penulis perempuan Amerika, Sui Sin Far dalam karyanya Its Wavering Image. Penulis tersebut dipilih karena dia merupakan a voice of the minority experience in America (suara kaum minoritas di Amerika) karena pikiran-pikirannya tentang kaum minoritas di Amerika, khususnya etnis Cina di Amerika(Solomon, 1994:27). Pada karya sastra ketidaksetaraan tersebut juga tampak seperti dikatakan oleh bahwa "Literature is the expression of society," (karya sastra adalah ekspresi masyarakat) (Levin, 1958:56). Artinya, masyarakat yang digambarkan oleh penulis dalam karyanya adalah masyarakat yang ada dalam dunia nyata tempat penulis tersebut hidup. Teori feminisme multikultural digunakan sebagai kerangka acuan untuk melihat ketidaksetaraan dan ketidakadilan yang disebabkan oleh perbedaan budaya, ras, atau etnis.

Pembicaraan tentang ras atau etnis lebih sering dikaitkan dengan stereotip yaitu kepercayaan berlebihan dan penggambaran tentang kelompok orang tertentu yang seringkali berdasarkan pada kurangnya informasi dan komunikasi serta mudah untuk menyamaratakan dan menerapkan 
tindakan dan perilaku beberapa orang dari kelompok tertentu kepada seluruh kelompok. Misalnya Cina-Amerika, Orang Cina dibawa ke Amerika dalam jumlah besar sebagai buruh atau kuli danundang-undang dan naturalisasi baru diizinkan menjadi warganegara atau naturalisasi pada tahun 1954 beberapa tahun setelah Afrika-Amerika dan Indian-Amerika diakui. Awalnya orang Cina tertarik ke California untuk mencari emas pada pertengahan abad kesembilan belas. Pada tahun 1860an ribuan buruh Cina datang ke Amerika tidak hanya mencari emas, tetapi untuk membangun jalan kereta api lintas pegunungan di bagian barat Amerika Serikat. Orang kulit putih telah berprasangka buruk terhadap mereka. Sejak awal kedatangan orang Cina, orang Amerika menganggap mereka sebagai ras dengan kebiasaan aneh, yaitu bekerja keras tanpa mengenal waktu, berhemat secara berlebihan, dan bersedia untuk bekerja dengan upah yang lebih rendah dibandingkan orang kulit putih. Hal ini dapat menjadi ancaman ekonomi bagi orang kulit putih. Akibatnya orang Cina di Amerika menjadi sasaran kekerasan rasial (Parrillo,1985: 241-252, Conlin, 1990: 523524).

Prasangka negatif juga dialami oleh Eaton atau Sui San Far yang berdarah Cina dari ayahnya dan Inggris dari ibunya seperti dikatakan oleh Ferree bahwa pengalaman perempuan minoritas tidak hanya merupakan penindasan atau penempatan perempuan lebih rendah,tetapi juga sekaligus penghilangan identitas diri (Ferree,2000: 94). Perasaan tersebut dialami selama bertahuntahun sehingga meresap dalam dirinya. Dengan mengambil nama yang populer di kalangan Cina, Sui Sin Far memiliki arti bunga bakung, dia telah memutuskan untuk mewarisi darah Cina, meskipun wajahnya tidak menunjukkan bahwa dia berasal dari etnis Cina (White-Parks, 1995). Dalam "Leaves" dia menjelaskan tentang kesadaran akan identitas etnisnya, kepekaan terhadap lingkungan dan komunitasnya. Dia dianggap sebagai penulis fiksi pertama sastra Asia Amerika, dan para kritikus melihat cerita- cerita Far sebagai pengalaman imigran Asia yang kompleks dalam pencarian identitas (Ling, 2003). Sebagai seorang anak perempuan dari seorang ibu berkebangsaan Inggris dan ayah berkebangsaan Cina yang dibesarkan di Chinatown, dia berjuang melawan ambivalensi terhadap identitas ras campuran dan internalisasi gagasan rasis yang terefleksi dalam karyanya Its Wavering Image.

\section{PEMBAHASAN}

Martabat sesungguhnya tidak dapat dikaitkan dengan hasil yang kasat mata. Ada nilai-nilai etika yang inheren dan tak dapat diabaikan dalam proses mencapai martabat. Proses tersebut menentukan kualitas keluhuran manusia. Apabila nilai-nilai tersebut diabaikan, maka martabat sebagai upaya meraih tingkat keluhuran dapat menjadi sesuatu yang merusak tata nilai. Oleh karena itu, Far menempatkan martabat sebagai nilai utama dalam kehidupan, khususnya masyarakat heterogen yang dijabarkan menjadi tiga aspek, yaitu intelektualitas, harmoni, dan kepercayaan yang diuraikan sebagai berikut.

\section{Intelektualitas}

Dalam Its Wavering Image, Sui Sin Far menggambarkan Man You melempar koran ke arah anak perempuannya, yaitu Pan. Sikap kasar yang belum pernah dilakukan Man You terhadap Pan, selama ini. Ayah Pan sangat marah dengan liputan yang dibuat oleh Mark, seorang reporter. Mark dalam laporannya menuliskan tentang kehidupan masyarakat Cina dari sudut pandangnya, dan menyebut Pan sebagai perempuan kulit putih yang memiliki kecerdasan dan pemahaman tentang masyarakat China. Kalimat tersebut sebenarnya merupakan ucapan seorang editor kepada Mark. "She is unusually bright girl, and could tell more stories about the Chinese than any other person in this city - if she could" (dia adalah gadis yang sangat cerdas, dan jika dia mampu, dia adalah yang paling mampu bercerita lebih banyak mengenai orang-orang Cina di antara orang-orang yang ada di kota 
ini) (Far, 1994:609). Mark menambahkan "she" dengan "a white woman". Pemberitaan tersebut secara tidak langsung menyatakan bahwa orang kulit putih dicitrakan sebagai etnis yang lebih unggul secara intelektualitas daripada orang Cina. Pada awal cerita Mark, seorang reporter kulit putih, datang ke Chinatown untuk mencari berita tentang kehidupan masyarakat Cina. Di bazaar dia bertemu dengan Pan yang tampilannya lebih tampak sebagai orang kulit putih daripada orang Cina. Keberadaan Pan yang dilihatnya sebagai perempuan kulit putih menimbulkan pertanyaan what is she? (Apa suku bangsanya?) Chinese or white? (Cina atau orang kulit putih?) (609). Menurut Mark, sangatlah berbahaya bagi seorang kulit putih, khususnya perempuan untuk berada di Chinatown karena daerah tersebut dianggap daerah rawan. Tidak berbeda dengan orang kulit putih lainnya dia menganggap bahwa orang China itu licik dan suka menipu (Parrillo, 1985: 62). Sebagai seorang reporter dia telah melakukan dua kesalahan, yaitu menulis pernyataan seseorang tanpa diolah terlebih dahulu, dan tidak memiliki kapasitas etnisitas dalam melakukan penelitian dengan objek yang bukan berasal dari ranah budayanya sendiri. Pernyataan editor tersebut diterapkan dengan tidak hatihati oleh Mark yang mengarah ke prasangka buruk. Mark juga tidak mempersiapkan diri dalam proses permulaan penulisan, yaitu antara lain menguasai bahasa lokal, memahami adat istiadat, keyakinan, dan kearifan lokal yang dapat diperoleh misalnya melalui pengalaman hidup bersama dengan masyarakatnya. Hanya dengan waktu 2 (dua) bulan setelah berkenalan dengan Pan, Mark telah menyusun laporannya. Waktu yang relatif singkat tersebut hanya akan memberikan hasil penelitian yang bersifat superfisial dan diragukan kesahihannya karena ditulis di luar ranah budayanya seperti dikatakan oleh Ganap bahwa penelitian tentang masyarakat seharusnya membutuhkan tenggang waktu yang lebih panjang. Kalau tidak, substansinya cenderung terabaikan, terpinggirkan, bahkan tersingkirkan (Ganap, 2012:165). Laporan seperti itu menunjukkan bahwa peneliti tidak memiliki konsep multikultural, yaitu konsep dengan cara pandang kesetaraan (Ganap, 2012: 157), seperti yang telah dilakukan Mark. Dia bahkan telah meletakkan intelektualitas sebagai pembeda orang Cina dan orang kulit putih. Pernyataan yang telah membuat Man You sangat marah karena martabatnya sebagai orang Cinatelah dilecehkan.

Pada perkembangannya, Mark menengarai Pan memiliki sifat yang dianggap kontradiktif. Menurutnya, sebagai seorang intelektual, Pan bertindak dan berpikir tidak logis. Sebagai seorang intelektual Pan seharusnya mengutamakan akal dibandingkan perasaan. Bagi Mark intelektualitas dikaitkan dengan akal. Persepsi ini sesuai dengan definisi intelektual yang terdapat dalam Kamus Besar Bahasa Indonesia (2007:437), yaitu cerdas, berakal dan berpikiran jernih berdasarkan ilmu pengetahuan. Definisi tersebut dikaitkan dengan orang terpelajar dan cendikia. Mark melihat buku-buku yang dibaca Pan menjadi pembeda antara Pan dengan dengan orangorang Cina. Dengan kualitas tersebut, Mark menempatkan Pan lebih tinggi derajatnya daripada orang Cina lainnya. Akan tetapi, bagi Pan intelektualitas tidak hanya berkenaan dengan pengetahuan, dan kecerdasan berpikir, tetapi melibatkan juga daya akal budi atau batin yang merupakan paduan akal dan perasaan untuk menimbang baik dan buruk. Dengan demikian, ada dua pemahaman kata intelektualitas. Pertama, intelektualitas mengacu hanya pada reason atau akal. Kedua, intelektualitas tidak hanya melibatkan akal tetapi juga emosi atau perasaan. Dengan demikian, intelektualitas mengacu tidak hanya pada kapasitas akal atau otak yang erat kaitannya dengan inteligensi atau kecerdasan tetapi juga daya akal budi atau cara berpikir dan berperasaan. Menurut Pan, seorang intelektual mempunyai kesadaran dan kepekaan yang tajam terhadap lingkungan sekelilingnya, dan menghayati sepenuhnya peran dalam budaya komunitasnya seperti yang dilakukannya. 
Bagi Pan intelektualitas adalah memahami budayanya, membangkitkan kesadaran tentang dirinya, dan membangun cinta sesama. Pan menyadari bahwa manusia tidak dilihat dari kemampuan pikir atau pengetahuan yang dimilikinya, tetapi perlu diseimbangkan dengan perasaan. Dengan demikian menurutnya manusia akan menjadi individu yang peka. Baginya rasionalitas yang dingin perlu diimbangi perasaan dan kepedulian. Oleh karena itu, pandangan dunia Pan bersifat subyektif dan relatif. Sedangkan, bagi Mark kebenaran dilihat dari objektivitas hasil olah pikir individu. Mark berpendapat bahwa kemampuan intelelektual berkaitan erat dengan ras atau etnis. Pendapat ini lebih sering dikaitkan dengan stereotip, yaitu konsepsi mengenai sifat suatu golongan berdasarkan prasangka yang subyektif dan tidak tepat (Kamus Besar Bahasa Indonesia, 2007: 1091).

Mark melihat Pan bukan sebagai perempuan, tetapi sebagai orang kulit putih yang mempunyai kedudukann lebih tinggi daripada orang kulit berwarna, khususnya dikaitkan dengan intelektualitas. Pemikiran ini yang mendominasi tulisan Mark tentang masyarakat Cina. Dengan menampilkan Pan dalam laporannya sebagai orang kulit putih terlihat bahwa dia telah merendahkan orang kulit berwarna. Pemikiran ini terlihat dalam beberapa ucapan dan tindakannya.

"Pan," he cried, "you do not belong here. You are white - white."

"No! no!" protested Pan.

"You are," he asserted. "You have no right to be here."

I was born here," she answered, "and the Chinese people took upon me as their own."

"But they do not understand you," he went on.

"Your real self is alien to them.

What interest have they in the books you readthe thoughts you think?

("Pan," serunya, "ini bukan tempatmu. Kamu berkulit putih - berkulit putih."

“Tidak! tidak! "protes Pan.

"Kamu berkulit putih, Pan," tegas Mark. "Kamu tidak punya hak untuk berada di sini."
"Saya lahir di sini," jawabnya, "dan orangorang Cina itu mengenggapku bagian dari mereka."

"Tapi mereka tidak memahamimu,"lanjut Mark." Dirimu yang sebenarnya asing bagi mereka. Mereka tidak tertarik dengan buku-buku yang kamu baca - pemikiranpemikiranmu) (610)

Dalam Its Wavering Image, selain Pan ditampilkan perempuan Cina lain yang memiliki kualitas tidak berbeda dengan Pan. Ucapan dan tindakannya pada waktu Pan sedang kehilangan percaya diri menunjukkan bahwa dia tidak hanya mempunyai kecerdasan akal, tetapi kecerdasan budi juga.

"Lo! Said the mother of the toddler. "Thou wilt bear a child thyself some day, and all the bitterness of this will pass away. And Pan, being a chine woman, was comforted. (613)

("Lo! Kata ibu dari anak kecil itu. "Sesungguhnya, kamu nanti akan punya anak sendiri, dan semua kepahitan hidup ini akan berlalu. Dan Pan, sebagai perempuan Cina merasa terhibur) (613)

Perempuan Cina tersebut sadar bahwa Pan bersedih karena sikap Man You, ayahnya. Selama ini ayahnya menghormati baik terhadap ibunya maupun dirinya. .

She was born a Bohemian, exempt from the conventional restrictions imposed upon either the white or Chinese woman: and the Oriental who was her father mingled with his affection for his child so great a respect for and trust in the daughter of the dead white woman, that everything she did or said was right to him. And Pan herself! (610)

(Dia terlahir sebagai seorang Bohemian, bebas dari batas-batas konvensional yang diberlakukan bagi wanita berkulit putih maupun wanita Cina: dan sisi oriental yang didapatkan dari ayahnya yang bercampur dengan kasih sayangnya dan besarnya rasa hormat dan percayanya terhadap putrinya yang dilahirkan oleh istrinya yang berkulit putih yang telah meninggal. Semua yang Pan lakukan atau katakan kepadanya adalah benar. Demikian juga dengan kehadiran Pan dalam hidupnya!) (610) 
Kutipan tersebut menunjukkan bahwa sikap saling menyayangi dan menghormati telah tercipta dalam keluarga Man You, suatu nilai yang diwariskan kepada anaknya yang merupakan kesinambungan dari masyarakat di mana dia hidup dari kecil sampai dewasa. Anaknya akan mewarisi nilai tersebut ke generasi yang selanjutnya seperti yang dikatakan oleh Whitehead (via Hadi, 1996:118) bahwa "pada dasarnya hidup manusia adalah pengalaman bersama, bahkan di dalam unsur-unsur hidup manusia yang paling individual merupakan kehidupan bersama dan tingkah laku manusia di dalam strukturnya selalu menunjuk kepada pribadi lain". Seorang anak tidak dapat hidup dan berkembang sebagai pribadi di dalam isolasi atau keterasingan dari masyarakat. Ia menghayati hidup bersama yang sifatnya komunikatif.

When she was lying low, the element of Fire having raged so fiercely within her that it had almost shriveled up the childish frame, there came to the house of Man You a little toddler who could scarcely speak. Climbing upon Pan's couch, she pressed her head upon the sick girl's bosom. The feel of that little head brought tears (613)

Ketika ia menyendiri, unsur api yang telah berkobar begitu dahsyat dalam dirinya membuat tubuhnya yang kekanak kanakan itu menjadi hampir layu . Lalu datanglah ke rumah Man You seorang anak kecil yang belum dapat berbicara. Anak itu naik ke sofa tempat Pan duduk dan menyandarkan kepalanya di dada gadis yang sedang sakit itu. Ketika merasakan kepala kecil itu di dadanya, Pan menangis (613)

Sejak awal seorang ibu telah mengajari anaknya untuk bersikap empati terhadap kesedihan atau kesulitan orang lain. Bocah tersebut didekatkan dan dibiarkan oleh ibunya mendekat dan menghibur Pan dengan caranya sendiri. Sebagai seorang perempuan Cina, ia tahu betul bagaimana memelihara dan membangun suatu hubungan antarpersonal. Pendekatan yang dilakukan ibu bocah tersebut menunjukkan bahwa seorang perempuan yang memiliki kematangan intelektualitas, yaitu menyeimbangkan akal dan budi sebagai bagian dari komunitas tersebut, Pan merasakan jalinan komunitas tersebut.

\section{Harmoni}

Keseimbangan akal budi yang dimiliki Pan dan ibu seorang bocah menciptakan kehidupan harmoni. Kalimat "Karena aku seorang perempuan Cina (613)" dan "Pan, sebagai perempuan Cina merasa terhibur (613)" merupakan kalimat-kalimat yang menegaskan kedudukan perempuan Cina dalam masyarakatnya. Perempuan Cina secara garis besar berkedudukan inferior dibandingkan laki-laki Cina (Ebrey, 2003:24). Mereka sangat menyadari hal tersebut. Perbedaan tersebut tidak mereka rasakan, terutama Pan karena ayahnya sangat menghormati sesama, baik yang lebih muda, jenis kelamin, maupun etnis lain. Perbedaan status laki-laki dan perempuan juga disikapi secara positif oleh kedua perempuan tersebut. Mereka memberi ruang pada diri mereka sendiri untuk mengukuhkan kedudukannya sebagai penyimpan dan pemburu mimpi serta mewariskannya kepada anak keturunannya seperti yang dilakukan oleh pendahulunya pada waktu datang ke Amerika (JuliasihKusharyanto, 2009:36). Sebagai anak perempuan keturunan Cina-Inggris yang tumbuh di Chinatown, Pan berjuang untuk memantapkan identitas dirinya. Secara fisik dia cenderung ke Anglo, tetapi jiwanya terikat pada komunitas Cina, khususnya terikat pada ayahnya. "I would rather have a Chinese for a father than a whiteman" (Saya lebih memilih mempunyai ayah Cina daripada orang kulit putih) (610). Sejak awal Pan lebih merasa nyaman dengan keluarga ayahnya daripada keluarga ibunya (608). Tingkah laku dan perbuatannya menunjukkan dia lebih cenderung sebagai perempuan Cina daripada perempuan kulit putih, dan tidak merasa berbeda dengan orang-orang Cina yang ada disekelilignya. Pernyataan Mark bahwa dirinya adalah perempuan kulit putih menyadarkan Pan bahwa dia tidak dapat berada diantaranya. Dia harus menentukan 
sikap terhadap pilihan kelompoknya. Hubungan dengan Mark justru menyadarkan dan menguatkan keputusannya sebagai orang Cina, dan membuat Pan menjadi lebih peka terhadap sekelilingnya.

Meanwhile, in full trust and confidence, she led him about Chinatown, initiating him into the simple mystery and history of many things, for which she, being of her father's race, had a tender regard and pride (609).

(Sementara itu, dengan kepercayaan dan kepercayaan diri yang penuh, dia memperkenalkan Chinatown kepada Mark, memaparkan kepadanya misteri-misteri kecil dan sejarah tentang banyak hal yang ia, sebagai orang Cina karena ayahnya, hormati dan banggakan (609).

Bahkan, ketika dia mendengar musik China yang dimainkan di restoran, Pan merasakan getaran keindahan yang selama ini tidak pernah dia rasakan.

A Chinese band played three evenings a week in the gilded restaurant beneath them, and the louder the gongs sounded and the fiddlers fiddled, the more delighted was Pan.

(Sebuah grup musik Cina bermain tiga malam dalam seminggu di restoran elit di bawah mereka. Semakin keras gong-gong itu dibunyikan dan semakin riang para pemain biola Cina itu memainkan biola mereka, maka Pan menjadi semakin senang) (610).

Demikian juga dengan Chinatown yang mendadak tampak menjadi lebih indah, hidup, dan terasa menyenangkan.

"Perhaps it isn't very beautiful," replied Pan, "but it is here I live. It is my home." Her voice quivered a little.

"Pan," he cried, "you do not belong here. You are white...white."

"No! No!" protested Pan (610)

("Mungkin tempat ini tidak begitu indah," jawab Pan, "tapi di sinilah saya tinggal. Ini rumah saya. "Suaranya sedikit bergetar.

"Pan," serunya, "Di sini bukan tempatmu. Kamu berkulit putih ... putih. "

“Tidak!Tidak! "Protes Pan) (610)
Pan mulai mengidentifikasi dirinya secara fisik yang sebelumnya tidak pernah dia lakukan. Dia yang biasanya berpakaian seperti perempuan kulit putih mulai mengenakan pakaian perempuan Cina pada waktu menemui Mark. Sikap ini menegaskan bahwa dia adalah perempuan Cina.

He had been accustomed to seeing her in American dress. Tonight she wore the Chinese costume. But for her clear-cut features she might have been a Chinese girl. He shivered.

"Pan," he asked, "why do you wear that dress?" Within her sleeves Pan's small hand struggled together; but her face and voice were calm.

"Because I am a Chinese woman," she answered (613)

(Mark sudah terbiasa melihat Pan berpakaian seperti para wanita Amerika. Malam ini dia memakai pakain tradisional Cina. Tapi dari wajahnya, Pan mungkin benar-benar bisa menjadi seorang gadis Cina. Mark merinding.

"Pan,"tanya dia, "kenapa kamu memakai pakaian itu?"

Di dalam lengan pakainnya yang panjang itu kedua tangan Pan mencoba untuk tidak gemetar, tapi wajahnya nampak tenang begitu juga suaranya.

"Karena aku seorang perempuan Cina, "jawabnya" (613)

Komentar Mark tentang pakaian yang dikenakannya membuat harga dirinya terhina. Dia tidak yakin seandainya dia memilih menjadi orang kulit putih, apakah dia dapat diterima dalam komunitas tersebut karena dalam dirinya mengalir darah ras yang dianggap inferior. Selama ini masyarakat Cina tempat dia tinggal tidak pernah mempersoalkan identitas dirinya. Mereka .menerima kehadirannya dengan sepenuh hati..

With her father's people she was natural and at home; but in the presence of her mother's she felt strange and constrained, shringking from their curious scrutiny as she would from the sharp edge of a sword (608)

(Ketika Pan berada di antara orang Cina, ia dapat bersikap apa adanya dan merasa nyaman; namun jika dia berada di antara 
orang kulit putih ia merasa aneh dan tidak bebas, ia lalu menghindar dari pandangan menyelidik mereka sebagaimana dia akan menghindari ujung pedang yang tajam) (608).

Kesadarannya akan ikatan spiritual pada nilai-nilai moral yang dianutnya selama ini membuat Pan tidak ragu menentukan pilihannya. Bagi Mark, tindakan Pan sangat bodoh karena dia memilih untuk menjadi orang Cina yang dianggapnya inferior. Hal ini menunjukkan bahwa apa yang tampaknya masuk akal, pantas, dan penting bagi suatu komunitas menjadi tampak bodoh, tidak masuk akal, dan tidak penting bagi komunitas lain. Ketika Pan memutuskan untuk menjadi bagian dari komunitas orang Cina, pada saat yang sama dia memutuskan hubungannya dengan Mark. Dia berani mengambil keputusan untuk dirinya sebagai wujud penghormatan terhadap nilai-nilai yang dijunjungnya selama ini. Pada tataran ini, Pan dapat merasakan dan memahami kemarahan ayahnya.

Pan menyadari bahwa dalam proses komunikasi dibutuhkan adaptasi yang terus menerus, kerjasama, dan saling terrgantung. Semua ini merupakan nilai-nilai penting dalam hidup bersama yang oleh Zhizhen (2008) disebut sebagai harmoni. Lebih lanjut dia menjelaskan bahwa proses komunikasi termasuk sopan santun, pembicaraan dari hati ke hati, dan perhatian yang tulus dapat membangun moral untuk saling mendukung dan membantu dalam menghadapi segala kesulitan seperti yang dilakukan Lo terhadap Pan yang berada dalam kesulitan (613).

Ikatan kuat dan harmonis antara sesama seperti yang disampaikan oleh Zhi zhen bahwa masyarakat dapat terjaga dan berkembang hanya bila harmoni terjaga. Bagi orang Cina harmoni merupakan hal penting yang digunakan untuk menghadapi perubahan dan merupakan proses komunikasi manusia yang tidak pernah berakhir. Tujuan utama dari komunikasi adalah untuk menghindari konflik, baik yang bersifat interpersonal maupun sosial. Ikatan yang kuat tidak hanya terjalin antar sesama, tetapi juga dengan para leluhur mereka yang mempunyai tempat terhormat dalam kehidupan mereka. Sumpah serapah "terkutuklah para nenek moyangnya" merupakan kata-kata yang menunjukkan puncak kemarahan seperti yang dilakukan Man You terhadap Mark karena masyarakatnya telah dihina secara keji.

"Cursed be his ancestors," bayed Man You. He cast a paper at his daughter's feet and left the room. Startled by her father's unwonted passion, Pan picked up the paper, and in the clear passionless light of the afternoon read that which forever after was blotted upon her memory.(612)

"Terkutuklah para nenek moyangnya," teriak Man You. Dia lemparkan koran di kaki putrinya lalu pergi dari ruangan itu. Terkejut oleh kemarahan ayahnya yang tak terduga, Pan mengambil koran itu dan membaca apa yang tertulis dalam cahaya matahari soreyang redup. Apa yang iabaca akan ia hapuskan selamanya dari ingatannya. (612)

Penghinaan Mark terhadap orang Cina disebabkan kurangnya informasi dan komunikasi serta mudah untuk menyamaratakan dan menerapkan tindakan dan perilaku beberapa orang dari kelompok tertentu kepada seluruh kelompok yang mengakibatkan rusaknya hubungan harmonis antarsesama. Hal ini, harmoni dapat dikatakan mengandung nilai toleransi, yaitu menghargai dan memahami bersama budaya satu sama lainnya seperti dilakukan oleh Man You dan Pan pada waktu menerima Mark. Cara Pan membanggakan budaya Cina kepada Mark menunjukkan adanya perbedaan antara dirinya dengan Mark. Dia sangat memahami perbedaan budaya kedua orang tuanya, bahkan dia merasa kedua budaya tersebut merupakan bagian dari dirinya, walaupun dia sendiri lebih memilih untuk menjadi bagian dari orang Cina karena sejak kecil dia telah berada di komunitas tersebut.

Berbeda dengan Pan yang menekankan pada harmoni, Mark cenderung untuk menekan pada perbedaan dibandingkan persamaan. Dia tidak membuka pikirannya 
untuk budaya lain. Sebagai seorang reporter dia berkewajiban untuk menyampaikan data dan fakta yang akurat tentang masyarakat Cina. Akan tetapi, justru dia yang mendeskreditkan masyarakat cina. Pikirannya sudah terbentuk dan terpola oleh hal-hal negatif tentang imigran Cina.Dia tidak dapat melihat kebaikan-kebaikan orang Cina termasuk keterbukaannya terhadap orang asing sekalipun.

Mark melihat bahwa prinsip kebersamaan merupakan sikap yang bertolak belakang dengan prinsip individualisme, yaitu "the belief that the needs of each person are more important than the needs of the whole society or group or the actions or attitudes of a person who does things without being concerned about what other people will think (keyakinan bahwa kebutuhan-kebutuhan setiap individu lebih penting dari kebutuhan-kebutuhan seluruh masyarakat atau kelompok atau tindakantindakan atau sikap-sikap dari seorang individu yang melakukan tindakan-tindakan tanpa mempertimbangkan reaksi atau respon dari orang lain) (http://www.merriamwebster.com/dictionary/individualism). Pemikiran Mark tersebut menyimpang dari pemikiran Hoover (via Margaret Hoover, 2002), seorang humanitarian dan wakil presiden Amerika ke 31 mengatakan sebagai berikut:

Each individual shall be given the chance and stimulation for development of the best with which he has been endowed in heart and mind; it is the sole source of progress; it is American individualism.

(setiap individu akan diberikan kesempatan dan stimulasi untuk pengembangan terbaik dengan apa yang telah dilimpahkan kepadanya di dalam hati dan pikirannya. Ini adalah satu-satunya sumber kemajuan.Ini adalah individualisme Amerika).

Pendapat Hoover tersebut menegaskan bahwa indidualisme menekankan pada kesempatan dan stimulasi untuk pengembangan terbaik dengan apa yang telah dilimpahakan kepadanya di dalam hati dan pikirannya dan bukan pada gagasan bahwa kebutuhan-kebutuhan individu lebih penting dari kebutuhan-kebutuhan masyarakat atau kelompok). Artinya, baik kebersamaan maupun individualisme tetap mempertimbangkan heart (hati) dan mind (akal). Apabila Mark memahami makna individualisme seperti yang disampaikan oleh Hoover, maka dia tidak akan memandang rendah masyarakat Cina.

Hubungan yang kuat antaranggota keluarga Cina tampak sekali dalam dialog antara Pan dan ibu bocah. Bagi mereka, ikatan kekeluargaan sangat penting. Mereka membangun ikatan yang saling menghargai yang menekankan pada dialog, dan jalinan persahabatan berdasarkan persamaan rasa. Pribadi yang hangat menyukai hubungan dengan orang lain merupakan dasar dari komunitas Cina. Mereka membuat keputusan dengan cara berekonsiliasi dan bersama-sama memperbarui spiritualitas. Mereka memegang teguh nilai-nilai persaudaraan, dan kepekaan terhadap lingkungannya. Bagi mereka keluarga tak ternilai harganya. Tidak perlu ada kata-kata, sentuhan anak kecil sekalipun merupakan suatu kekuatan untuk menentukan sikap dan memutuskan apa yang dilakukan (613). Cinta bagi Pan tidak hanya melibatkan dua orang, tetapi juga melibatkan keluarga.

Kesalahpahaman dalam pemaknaan dan tidak adanya kepekaan terhadap perbedaan menimbulkan konflik seperti yang terjadi antara Man You, Pan, dan Mark. Untuk memahami kehalusan, seluk beluk, dan kepekaan terhadap jaring-jaring budaya komunitas lain diperlukan pengalaman dan kajian mendalam serta tidak dilihat hanya sesaat seperti yang dilakukan Mark Carson. Dia bermaksud untuk mengangkat derajat Pan agar sama dengan orang kulit putih dengan mengatakan bahwa Pan adalah seorang kulit putih, tetapi akibatnya adalah menyinggung martabat tidak hanya individu, tetapi juga masyarakat Cina, khususnya Man You, ayah Pan.

\section{Kepercayaan}

Hubungan Harmonis yang tercipta di antara komunitas Cina dirusak oleh 
Mark yang menyalahgunakan kepercayaan yang diberikan kepadanya.Pan tidak berkeberatan untuk menjelaskan kepada Mark tentang kehidupan masyarakat Cina. Man You mengizinkan Pan mengajak Mark untuk mengunjungi tempat-tempat yang sebelumnya tidak pernah dikunjungi oleh orang asing. Izin tersebut diberikan kepada Pan dan Mark karena dia percaya bahwa mereka tidak akan melanggar etika yang berlaku.Berkat Pan dan ayahnya, Mark Carson diterima ditempat-tempat yang selama ini dianggap misteri, bahkan Mark dianggap saudara dan anggota kehormatan.

For her sake he was received as a brother by the yellow-robed priest in the joss house, the astrologer of prospect place, and other conservative Chinese. The Water Lily Club opened its doors to him when she knocked, and the Sublimely Pure Brothers' organization admitted him as one of its honorary members, thereby enabling him not only to see but to take part in a ceremony in which no American had ever before participated. With her by his side, he was welcomed wherever he went. (609)

(Demi Pan, Mark diterima sebagai saudara laki-laki oleh seorang pendeta Cina berjubah kuning di sebuah klenteng, seorang peramal (peramalnya Prospect Place), dan juga oleh orang-orang Cina yang konservatif lainnya. The Water Lily Club menerima Mark ketika Pan memintanya, dan organisasi Sublimely Pure Brothers menerima Mark sebagai salah satu anggota kehormatanny. , ini membuat dia bisa untuk tidak hanya melihat tetapi untuk juga mengambil bagian dalam sebuah upacara di mana belum pernah ada orang Amerika yang berpartisipasi. Dengan Pan di sisinya, ia diterima ke mana pun ia pergi). (609)

Bagi mereka kepercayaan adalah keyakinan akan kejujuran dan kebaikan yang merupakan nilai yang selalu ditanamkan oleh masyarakat Cina sebagai bagian dari hidup bersama (Chua, http://www.people.hbs.edu/rchua/ Guanxi\%20network.pdf). Komunitas ini dibangun berdasarkan kepercayaan. Yellowrobed priest, astrologer, dan Water-Lily Club menunjukkan masyarakat Cina menghargai aktivitas-aktivitas yang berkaitan erat dengan spiritual yang menurut Mark tidak rasional. Mark tidak paham bahwa keyakinan atau kepercayaan yang mereka anut membuat hidup mereka menjadi lebih jelas, terarah, dan tenang. Mereka lebih mudah untuk mengatasi permasalahan karena mereka percaya bahwa hidup yang mereka jalani di dunia ini sudah ada yang mengatur. Kajian yang dilakukan Mark secara sepintas menimbulkan ketegangan tidak hanya bagi Pan dan Mark, tetapi juga dengan komunitas Cina. Mark dianggap pengkhianat yang merupakan perbuatan yang sulit diampuni karena tidak memegang kepercayaan yang diberikan kepadanya.

$\mathrm{He}$ (Man You) cast a paper at his daughter's feet and left the room....

"Betrayed! Betrayed! Betrayed to be a betrayer!" It burnt red hot; agony unrelieved by words, unassuaged by tears (612)

Dia (Man You) lemparkan koran di kaki putrinya lalu pergi dari ruangan itu. . . . ."Dikhianati! Dikhianati! Dikhianati untuk menjadi pengkhianat " Kemarahannya membara; kepedihan yang tidak bisa disembuhkan dengan kata-kata, tak terhapuskan oleh air mata) (612).

Teriakan "pengkhianat" sampai 3 (tiga) kali, diikuti kalimat "dikhianati untuk menjadi pengkhianat" mengekspresikan ketidakmampuan Man You menahan diri untuk tidak berpikir negatif terhadap orang kulit putih. Perbuatan Mark memicu Man You untuk melakukan hal yang sama terhadap orang kulit putih. Bagi masyarakat Cina, Mark adalah perusak tata nilai.

Uraian di atas menunjukkan bahwa dalam menggambarkan tokohnya, Sui Sin Far merefleksikan sesuai dengan persepsinya. Dia menggambarkan sosok perempuan lewat tokohnya, tidak hanya secara fisik juga pergulatan batinnya. Lewat tokohnya, dia menawarkan beberapa alternatif bentuk pemikiran lain. Di dalam karyanya, dia berargumentasi dan merefleksikan persepsinya tentang kesetaraan yang yang erat kaitannya dengan harkat dan martabat, 
Dia bahkan melihat martabat itu sendiri mengandung nilai-nilai yang terlihat dalam beberapa tindakan dan pikiran para tokohnya. Pan, tokohnya memegang teguh prinsip dalam memilih tindakannya. Dalam keputusannya dia mempertimbangkan martabat yang dipertaruhkan, yaitu martabat sebagai etnis Cina yang melekat pada setiap komunitas.

\section{SIMPULAN}

Berdasarkanuraiandiatas, teridentifikasi bahwa ketidaksetaraan dalam Its Wavering disebabkan oleh perbedaan etnis daripada jenis kelamin. Orang kulit putih baik laki-laki atau perempuan berkedudukan lebih tinggi daripada kulit berwarna (Cina Amerika). Bagi perempuan Cina, kedudukannya tidak hanya lebih rendah daripada laki-laki dalam masyarakatnya, tetapi juga lebih rendah dari perempuan kulit putih.Perempuan Cina mengalami dobel ketidaksetaraan. Untuk mengeliminasi ketidaksetaraan tersebut Sui San Far menawarkan martabat sebagai nilai penting dalam kehidupan masyarakat yang heterogen seperti di Amerika. Kata tersebut baru dapat dipahami melalui konteks yang dibangun oleh Sui Sin Far. Menurutnya martabat memiliki pengertian pertama, kemampuan membangkitkan kesadaran tentang dirinya dan memahami budayanya sebagai hasil olah akal budi; kedua, kemampuan membangun dan mengembangkan hubungan yang harmonis antarmereka, yaitu hubungan yang terus menerus berinteraksi dan saling bergantung dalam proses perubahan; ketiga kemampuan untuk memegang kepercayaan. Nilai-nilai tersebut bersifat universal. Oleh karena itu, untuk menjadi orang Amerika tidak harus terlihat, bertindak, dan berpikir serupa. Yang dperlukan dalam masyarakat heterogen adalah menumbuhkan toleransi, penghargaan, dan pengetahuan bersama atas kebudayaan satu sama lain. Artinya, setiap individu, etnis, atau bangsa mempunyai keunikan masing-masing yang keberadaannya tetap terjaga dalam masyarakat yang majemuk. Hubungan yang tercipta diantara komunitas adalah kemampuan untuk mengenali kapasitas sebagai penyampai pemikiran-pemikiran tentang kemanusiaan, khususnya kesetaraan. Mereka yang mampu hidup dalam masyarakat yang heterogen pantas untuk disebut sebagai masyarakat bermartabat karena mampu mewujudkan perdamaian.

Hubungan harmonis yang tercipta diantara sesamanya termasuk hubungan laki-laki dan perempuan menghilangkan prasangka di antara mereka. Perempuan China-Amerika memiliki konsep kesetaraan sendiri sesuai dengan nilai-nilai mereka. Kesetaraan menurut mereka tetap terjaga selama memegang teguh martabat yang secara inheren di dalamnya terkandung intelektualitas, harmoni, dan kepercayaa, Ketiga aspek tersebut tidak berdiri sendirisendiri, tetapi saling terjalin dan terkait antara satu aspek dengan aspek yang lain.

\section{DAFTAR PUSTAKA}

Butler, Judith. 2004. Undoing Gender. New York: Routlegde.

Chua, Roy Yong-Joo dan Michael W. Morris. Dynamics of Trust in Guanxi Networks. http:/ / www.people.hbs.edu / rchua/Guanxi\%20network.pdf.

Conlin, Joseph R. 1990. The American Past. New York: Harcourt Brace Jovanovich, Publishers.

Davis. Angela Y.1983. Women, Race, and Class. New York: Random House.

Dinnerstein, Leonard dan David M. Reimers. 1977. Ethnic Americans: A History of Immigration and Assimilation. New York: New York University Press.

Ebrey, Patricia Beckley. 2003. Women and the Family in Chinese History. London: Routledge.

Far, Sui Sin. "Leaves from the Mental Portfolio of an Eurasian." Independent 66 (January 21, 1909: 125- 32.

.1994. "Its Wavering" dalam Rediscoveries: American Short Stories by Women, 1832-1916. Oleh Barbara 
H.Solomon (ed). New York: A Mentor Book.

Ferree, Myra Marx dan Beth B. Hess. 2000. Controversy and Coalition. The New Feminists Movement Across Four Decades of Change. New York: Routledge.

Ganap, Victor. 2004. “Konsep Multikultural dan Etnisitas Pribumi dalam Penelitian Seni dalamHumaniora, Volume 24, Nomor 2, Juni 2012. Yogyakarta: Fakultas Ilmu Budaya Universitas Gadjah Mada.

Gilman, Sander L. 2006. Multiculturalism and the Jews. New York: Routledge.

Hadi, Hardono. 2000. Jati diri manusia. Berdasar filsafat organisme Whitehead. Yogyakarta: penerbit Kanisius.

Hooks, Bell. 1990. Yearning: Race, Gender, and Cultural Politics. Cambridge: South End Press. 2000. Feminist Theory From Margin To Center. Cambridge: South End Press.

Hoover, Margaret. 2002. American Individualism: Herbert Hoover's American Social Philosophyhttp:// www.hooverassociation.org/ hoover/americanindv/american_ individualism_chapter.php, diunduh Minggu 27 Januari 2013.

Juliasih-Kusharyanto. $2009 . \quad$ Potensi Perempuan Amerika. Tinjauan Feminisme. Yogyakarta: Gadjah Mada University Press.

Kamus Besar Bahasa Indonesia.2007. Pusat Bahasa, Departemen dan Kebudayaan Indonesia: Balai Pustaka.

Kymlicka, W. 1995.Multicultural Citizenship: A Liberal Theory of Minority Rights. Oxford: Clarendon Press.
Levin, Harry T. 1958. Context of Criticism. Cambridge: Harvard University Press.

Ling, Amy. Edith Maude Eaton (Sui Sin Far) (1865-1914).http:// faculty. georgetown.edu/bassr/heath/ syllabuild/iguide/eaton.html.

Merriam Webster. 2014, http://www. merriam-webster.com/dictionary/ individualism.Okin, Susan Moller.1999. Is Multiculturalism Bad For Women?. Princeton: Princeton University Press.

Parrillo, Vincent N. 1985. Strangers to These Shores. Race and Ethnic Relations in the United States. New York: Macmillan Publishers.

Ratna, Nyoman Kutha, 2004. Teori, Metode, dan Teknik Penelitian Sastra. Yogyakarta: Pustaka Pelajar.

Solomon, Barbara H. 1994. Rediscoveries: American Short Stories by Women 1832-1916. New York: Penguin Books USA Inc.

Tong, Rosemarie Putnam. 2008. Feminist Thought. Diterjemahkan oleh Kurniasih. Yogyakarta: Jalasutra.

Tronto, Joan C. 2006. "Moral Perspectives: Gender, Ethics, and Political Theory" dalam Gender and Women's Studies (ed) Kathy Davis, Mary Evans, dan Judith Lorber. London: Sage Publications.

Universal Declaration of Human Rights. 2008. New Zealand: Aotearoa.

White-Parks, Annette. 1995. Sui Sin Far/Edith Maude Eaton: A Literary Biography. Urbana: University of Illinois Press.

Zhizhen. 2008Harmony-One of the Most Precious Elements in Chinese Traditional Culture.(http://www.theepochtimes. com/n2/china-news / harmonychinese-culture-5300.html). 